\title{
Establishment of an adherent cell layer from human umbilical cord blood
}

\author{
Zeni Z.C. Alfonso ${ }^{1}$, Eduardo D. Forneck ${ }^{l}$, Waldir F. Allebrandt ${ }^{2}$ and Nance B. Nardi ${ }^{l}$
}

\begin{abstract}
In addition to bone marrow and peripheral blood, stem cells also occur in human umbilical cord blood (HUCB), and there is an increasing interest in the use of this material as an alternative source for bone marrow transplantation and gene therapy. In vitro hematopoiesis has been maintained for up to 16 weeks in HUCB cultures, but the establishment of an adherent, stromal layer has consistently failed. Adherent cell precursors among mononuclear cells from HUCB were sought for in long-term cultures. Mononuclear cells obtained from cord blood after full term, normal deliveries were cultivated at different concentrations in Iscove's modified Dulbecco's medium (IMDM) with weekly feeding. An adherent layer was detected in 16 of 30 cultures, 12 of which were plated at cell concentrations higher than $2 \mathrm{x}$ $10^{6} \mathrm{cells} / \mathrm{ml}$. In contrast to bone marrow cultures, in which the stroma is detected early, in most (10/16) positive cultures from HUCB the adherent layer was identified only after the fourth week of culture. The cells never reached confluence and detached from the plate approximately four weeks after detection. May-Grünwald-Giemsa staining of positive cultures revealed fibroblast- or endothelial-like adherent cells in an arrangement different from that of bone marrow stroma in 13 samples. In two of these, the adherent cells were organized into characteristic, delimited cords of cells. Unlike bone marrow cultures, fat cells were never observed in the adherent layers. A rapid development of large myeloid cells in the first week of culture was characteristic of negative cultures and these cells were maintained for up to 12 weeks. HUCB contains adherent cell precursors which occur in lower numbers than in bone marrow and may be at a different (possibly less mature) stage of differentiation.
\end{abstract}

\section{INTRODUCTION}

Circulating blood cells originate from the proliferation and differentiation of a small subset of hematopoietic cells known as stem/progenitor cells. During adult life, hematopoiesis occurs mainly in the bone marrow, where stem cells represent up to $0.05 \%$ of the bone marrow cell population (Morrison et al., 1995). Hematopoiesis depends on the association of stem cells with non-hematopoietic adherent cells - the stroma - and their products (such as extracellular matrix and growth factors). These fixed cells are arranged in hematopoietic microenvironments in the medullar cavity of the bones. Several studies have demonstrated the importance of physiological interactions between the hematopoietic system and the microenvironmental compartment (Gordon, 1994; Mayani, 1996; Gordon et al., 1997). Similarly, the in vitro maintenance and differentiation of stem/progenitor cells is dependent on the establishment of a layer of adherent stromal cells, originally described by Dexter et al. (1977). Whether stromal and hematopoietic cells have a common origin is still controversial and our knowledge of the spatial organization and the sequence of functional interactions between stromal and stem cells is still very incomplete, mainly because of the difficulty in studying stroma in vivo.

In addition to bone marrow and peripheral blood, stem cells are also found in human umbilical cord blood (HUCB), and there is an increasing interest in the use of this material as an alternative source for bone marrow transplantation (Broxmeyer et al., 1992; Harris et al., 1994; Broxmeyer and Cooper, 1997) and gene therapy (Clapp and Williams, 1995). However, phenotypic and functional differences between cells from bone marrow or peripheral blood versus HUCB have been reported (Mayani and Lansdorp, 1995; Milosevits et al., 1995; Hao et al., 1995). Hematopoiesis has been maintained in cultures of HUCB for up to 16 weeks using irradiated bone marrow stroma, but the establishment of an adherent layer from HUCB has consistently failed (Hows et al., 1992). This has been explained by an inadequate number of stromal precursor cells in the HUCB or by the different adhesive properties of cells in this material (Thierry et al., 1992). We describe a cell culture system which allows the development of an adherent, stromal-like cell population from $\mathrm{HUBC}$ mononuclear cells.

\section{MATERIAL AND METHODS}

Thirty HUCB samples (mean volume collected $=76.8$ $\mathrm{ml}$; range 30-110) were analyzed in this study. Human umbilical cord blood was collected into sterile blood bags (Hemobag, São Paulo, Brazil) containing citrate-phosphatedextrose, after full-term (40-42 weeks), normal deliveries, after clamping of the cord during vaginal deliveries at the Hospital de Clínicas de Porto Alegre and Hospital Nossa

\footnotetext{
${ }^{1}$ Departamento de Genética, Universidade Federal do Rio Grande do Sul, Caixa Postal 15053, $91501-970$ Porto Alegre, RS, Brasil. Send correspondence to N.B.N. Fax: +55-51-319-2011. E-mail: nardi@vortex.ufrgs.br

${ }^{2}$ Hospital Nossa Senhora da Conceição, Av. Francisco Trein, 526, 91350-200 Porto Alegre, RS, Brasil.
} 
Senhora da Conceição (Porto Alegre, RS, Brazil). The Ethics Committee approved this project. All samples were obtained after informed consent according to institutional guidelines. Within $24 \mathrm{~h}$ of collection, light density mononuclear cells were separated by centrifugation on FicollHypaque 1.077 (Hystopaque, Sigma, St. Louis, MO, USA) at $400 \mathrm{~g}$ for $30 \mathrm{~min}$. As this method, conventionally used for the isolation of mononuclear cells from peripheral blood, consistently resulted in a heavy contamination with red cells, an enrichment step with 3\% gelatin (Sigma) in $0.9 \%$ saline was used before centrifugation on FicollHypaque. Cord blood was mixed with gelatin $(1: 1, \mathrm{v}: \mathrm{v})$ and incubated at room temperature for $2 \mathrm{~h}$. The mononuclearenriched supernatant was collected and centrifuged (10 min, $400 \mathrm{~g}$ ) and the pellet was centrifuged on Ficoll-Hypaque. Cell viability as assessed with Trypan blue was greater than 95\% in all experiments.

After washing, the cells were suspended $\left(10^{6}-4 \times 10^{6}\right.$ cell $/ \mathrm{ml}$ ) in stroma medium consisting of Iscove's modified Dulbecco's medium (Sigma) containing 15\% horse serum, $15 \%$ fetal calf serum (Cultilab, São Paulo, Brazil), $20 \mathrm{mM}$ glutamin (Sigma), $100 \mathrm{mM} \beta$-mercaptoethanol
(Sigma), $10^{-6} \mathrm{M}$ hydrocortisone (Sigma), $50 \mathrm{U} / \mathrm{ml}$ penicillin (Sigma) and $50 \mu \mathrm{g} / \mathrm{ml}$ streptomycin (Sigma). The cells were dispensed into six-well culture plates (Corning, NY, USA) at $5 \mathrm{ml}$ per well, and the cultures were maintained at $37^{\circ} \mathrm{C}$ in a humidified atmosphere of $5 \% \mathrm{CO}_{2}$ in air. Half of the culture medium was replaced weekly with fresh medium. The cultures were examined by two independent observers once a week, using a phase contrast microscope (Carl-Zeiss, Germany). In some cases, the cells were stained with May/Grünwald/Giemsa stain.

\section{RESULTS AND DISCUSSION}

The formation of an adherent, stroma-like cell layer was observed in 16 of 30 samples. Higher cell concentrations were more favorable to the development of the adherent layer, since only four of the 16 positive cultures (with an adherent layer) were plated at concentrations up to $2 \times 10^{6}$ cells $/ \mathrm{ml}$. In contrast to bone marrow cultures in which the stroma develops rapidly (Hows et al., 1992), in most (10/16) of the positive cultures in our study the adherent layer was identified only after four weeks (Table I).

Table I - Formation, detection time and phenotype of an adherent layer in human umbilical cord cell cultures initiated with different cell concentrations.

\begin{tabular}{|c|c|c|c|c|c|}
\hline Sample & $\begin{array}{c}\text { Volume } \\
\text { collected (ml) }\end{array}$ & $\begin{array}{l}\text { Concentration } \\
(\text { cells } / \mathrm{ml})\end{array}$ & Result $^{1}$ & $\begin{array}{l}\text { Detection } \\
\text { (weeks) }\end{array}$ & Phenotype $^{2}$ \\
\hline 1 & 30 & $2 \times 10^{6}$ & - & - & - \\
\hline 2 & 35 & $2 \times 10^{6}$ & + & 4 & $\mathrm{CB}$ \\
\hline 3 & 50 & $2 \times 10^{6}$ & + & 6 & $\mathrm{CB}$ \\
\hline 4 & 90 & $2 \times 10^{6}$ & - & - & - \\
\hline 5 & 80 & $2 \times 10^{6}$ & + & 11 & CB \\
\hline 6 & 85 & $2 \times 10^{6}$ & + & 4 & $\mathrm{CB}$ \\
\hline 7 & 65 & $10^{6}$ & - & - & - \\
\hline 8 & 90 & $2 \times 10^{6}$ & - & - & - \\
\hline 9 & 65 & $2 \times 10^{6}$ & - & - & - \\
\hline 10 & 110 & $3 \times 10^{6}$ & - & - & - \\
\hline 11 & 110 & $4 \times 10^{6}$ & + & 5 & CB-c \\
\hline 12 & 50 & $2 \times 10^{6}$ & - & - & - \\
\hline 13 & 60 & $2 \times 10^{6}$ & - & - & - \\
\hline 14 & 90 & $3 \times 10^{6}$ & + & 3 & $\mathrm{CB}$ \\
\hline 15 & 80 & $3 \times 10^{6}$ & - & - & - \\
\hline 16 & 85 & $2 \times 10^{6}$ & - & - & - \\
\hline 17 & 70 & $3.2 \times 10^{6}$ & + & 5 & BM \\
\hline 18 & 85 & $4 \times 10^{6}$ & - & - & - \\
\hline 19 & 80 & $3.2 \times 10^{6}$ & + & 5 & BM \\
\hline 20 & 100 & $3.2 \times 10^{6}$ & + & 1 & BM \\
\hline 21 & 100 & $3.2 \times 10^{6}$ & + & 1 & $\mathrm{BM}$ \\
\hline 22 & 100 & $3.2 \times 10^{6}$ & + & $6-7$ & CB-c \\
\hline 23 & 50 & $3.5 \times 10^{6}$ & - & - & - \\
\hline 24 & 60 & $2.6 \times 10^{6}$ & - & - & - \\
\hline 25 & 80 & $3.2 \times 10^{6}$ & + & $5-6$ & CB \\
\hline 26 & 70 & $3.2 \times 10^{6}$ & + & 9 & $\mathrm{CB}$ \\
\hline 27 & 80 & $3.2 \times 10^{6}$ & - & - & - \\
\hline 28 & 80 & $3.2 \times 10^{6}$ & + & 5 & CB \\
\hline 29 & 80 & $3.2 \times 10^{6}$ & + & 5 & $\mathrm{CB}$ \\
\hline 30 & 95 & $3 \times 10^{6}$ & + & 4 & $\mathrm{CB}$ \\
\hline
\end{tabular}

${ }^{1}$ Positive and negative refer to the presence and absence of an adherent layer. ${ }^{2} \mathrm{CB}$ and $\mathrm{BM}$ refer to the cord blood- and bone marrow-like phenotypes, respectively, whereas CB-c refers to cultures in which the adherent layer was organized into characteristic cords. 
The cells never reached confluence and detached from the plate bottom four weeks after detection.

The rapid development of large myeloid cells (identified by their morphology) in the first week of culture was characteristic of negative cultures. These cells (Figure 1A) survived for up to 12 weeks. The absence of an adherent layer in the negative cultures suggested the release of some type of inhibitory molecule by the myeloid cells, as has been reported for murine bone marrow (Golialei et al., 1995). Another possible inhibitory mechanism may involve physical contact between the stromal precursors and myeloid cells. Such a regulatory mechanism is already known for lymphopoiesis (Tang et al., 1997), where TGF-beta was shown to play a significant role as a negative regulator of stroma-dependent proliferation of early human lymphoid progenitors.

Morphological examination of positive cultures revealed two phenotypes, denominated bone marrow- and cord blood-type, respectively (Figure 1B,C). Both phenotypes never occurred in the same culture. The main difference between the two consisted of a predominance of fibroblast-like cells in bone marrow-type cultures and an endothelial appearance in the cord blood phenotype. The latter phenotype was more common; in only three samples did the arrangement resemble that of bone marrow, although the cultures were not confluent.

Heterogeneity in the adherent layers during the in vitro development of hematopoietic tissues has already been reported. Wilkins and Jones (1995) demonstrated morphological and antigenic heterogeneity as well as temporal changes among subpopulations of stromal fibroblasts and macrophages in human bone marrow cultures. Sternberg et al. (1996) showed that bFGF (basic fibroblast growth factor) changed the cellular organization of stromal cells and that these modifications were related to alterations in the modified capacity to support hematopoiesis in culture. Thus, the different aspects of the cord blood adherent layers described here may reflect normal changes in precursor cells during ontogeny or may result from the establishment of different populations such as endothelial or fibroblast cells.

In two of the 16 positive cultures, the adherent cells were organized into characteristic and delimited cords of cells (Figure 1D). This type of arrangement has already
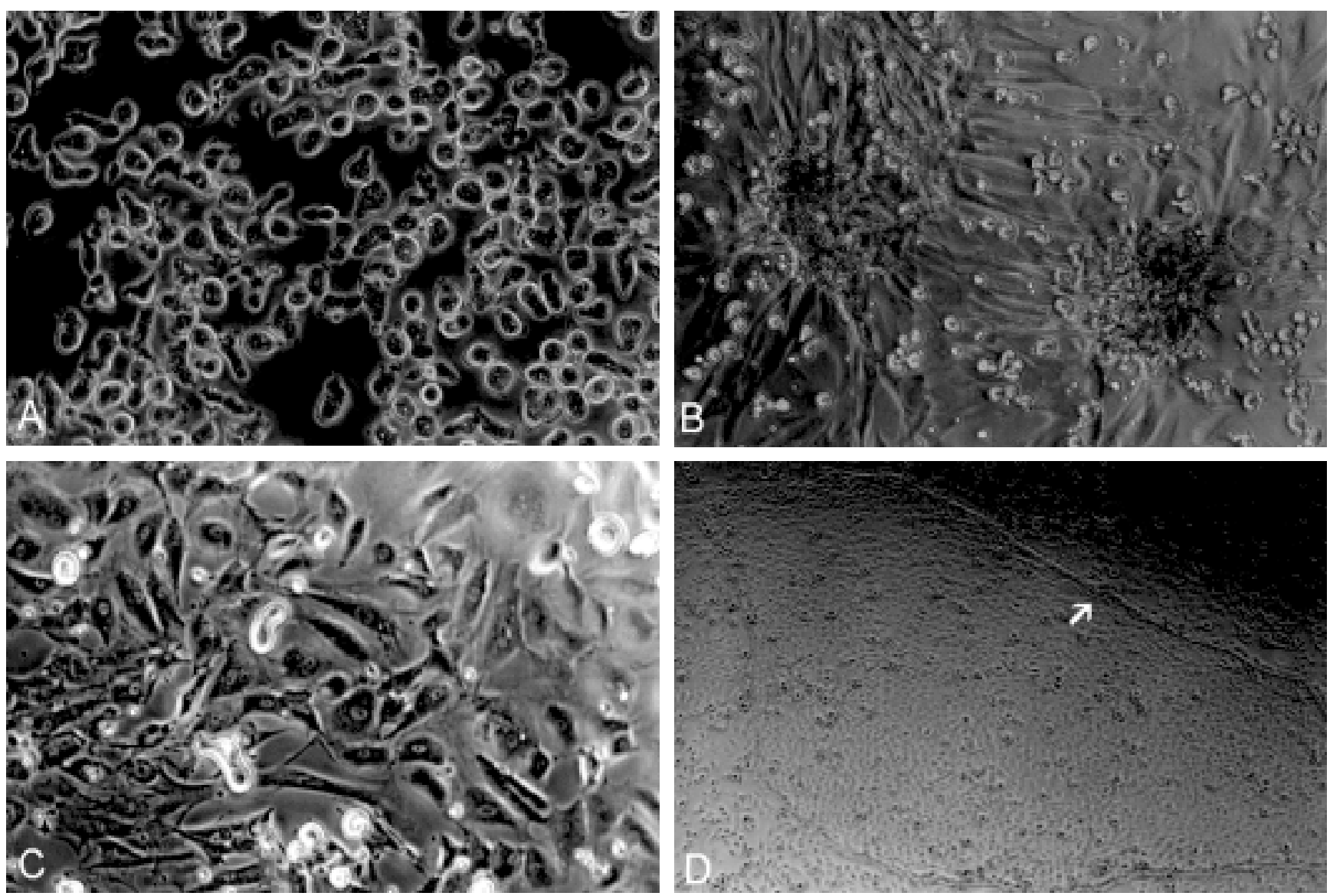

Figure 1 - Morphology of cultured cord blood cells photographed with an inverted microscope. A, Large myeloid cells whose appearance in the first week correlated with the occurrence of negative cultures (200X). B, Bone marrow-type adherent cells, showing mainly fibroblast-like cells (100X). C, Cord blood-type adherent cells, with predominantly endothelial-like cells (200X). D, Cord of cells (arrows) detected in two of the 16 positive cultures (40X). 
been described for bone marrow cultures derived from single stromal cells (Waller et al., 1995).

In contrast to bone marrow cultures, we never observed fat cells in the cord blood adherent layers. This finding differs from that reported by Ye et al. (1994), although the reasons for this discrepancy are unclear. Although, with advancing age, marrow stromal cells can differentiate along an adipogenesis pathway, the exact function of these cells is still not clear (Gimble et al., 1995).

In conclusion, stromal cell precursors are present in human umbilical cord blood, but occur at lower numbers than in bone marrow and may be at a different stage of differentiation. Detailed characterization of this adherent layer, including an evaluation of their ability to support hematopoiesis, is currently underway.

\section{ACKNOWLEDGMENTS}

This research was supported by FINEP and CNPq.

\section{RESUMO}

As células-mãe são encontradas no sangue do cordão umbilical humano (HUCB), além de na medula óssea e no sangue periférico, e há um crescente interesse no uso desse material como uma fonte alternativa para transplante de medula óssea e terapia gênica. A hematopoiese in vitro tem sido mantida por até 16 semanas em culturas de HUCB, mas o estabelecimento de uma camada estromal aderente tem invariavelmente falhado. Precursores de células aderentes foram pesquisados entre células mononucleares do HUCB em culturas a longo prazo. Células mononucleares obtidas do sangue do cordão depois de partos normais a termo foram cultivadas em diferentes concentrações em meio Dulbecco modificado por Iscove, com alimentação semanal. Uma camada aderente foi detectada em 16 de 30 culturas, 12 das quais em concentrações celulares maiores que 2 x $10^{6}$ células $/ \mathrm{ml}$. Ao contrário das culturas de medula óssea, em que o estroma é detectado precocemente, na maioria (10/16) das culturas positivas do HUCB a camada aderente foi identificada apenas depois da quarta semana de cultura. As células nunca atingiram a confluência e se destacaram da placa aproximadamente quatro semanas após sua detecção. A coloração de culturas positivas por May-Grünwald-Giemsa revelou células aderentes semelhantes a fibroblastos ou semelhantes a células endoteliais em um arranjo diferente daquele do estroma da medula óssea em 13 amostras. Em duas dessas, as células aderentes estavam organizadas em cordões característicos e delimitados de células. Ao contrário das culturas de medula óssea, células gordurosas nunca foram observadas nas camadas aderentes. Um rápido desenvolvimento de grandes células mielóides na primeira semana de cultura foi característico de culturas negativas e essas células mantiveram-se por até 12 semanas. HUCB contém precursores de células aderentes que ocorrem em números menores do que na medula óssea e podem estar em um estágio diferente (possivelmente menos maduro) de diferenciação.

\section{REFERENCES}

Broxmeyer, H.E. and Cooper, S. (1997). High-efficiency recovery of immature haematopoietic progenitor cells with extensive proliferative ca- pacity from human cord blood cryopreserved for 10 years. Clin. Exper. Immunol. 107: 45-53.

Broxmeyer, H.E., Hangoc, G., Cooper, S., Ribeiro, R.C., Graves, V., Yoder, M., Wagner, J., Vadhan-Raj, S., Benninger, L., Rubinstein, P. and Broun, R. (1992). Growth characteristics and expansion of human umbilical cord blood and estimation of its potential for transplantation in adults. Proc. Natl. Acad. Sci. USA 89: 4109-4113.

Clapp, D.W. and Williams, D.A. (1995). The use of umbilical cord blood as a cellular source for correction of genetic diseases affecting the hematopoietic system. Stem Cells 13: 613-621.

Dexter, T.M., Allen, T.D. and Lajtha, L.G. (1977). Conditions controlling the proliferation of haematopoietic stem cells in vitro. J. Cell. Physiol. 91:335-344.

Gimble, J.M., Morgan, C., Kelly, K., Wu, X., Dandapani, V., Wang, C.-S. and Rosen, V. (1995). Bone morphogenetic proteins inhibit adipocyte differentiation by bone marrow stromal cells. J. Cell. Biochem. 58: 393-402.

Golialei, B., Soheili, Z., Behboodi, A. and Samiei, S. (1995). Hematopoiesis in the presence of macrophages in long-term bone marrow cultures. Exp. Hematol. 23: 1115-1120.

Gordon, M.Y. (1994). Physiology and function of the haemopoietic microenvironment. Br. J. Haematol. 86: 241-243.

Gordon, M.Y., Lewis, J.L., Marley, S.B., Grand, F.H. and Goldman, M.J. (1997). Stromal cells negatively regulate primitive haemopoietic progenitor cell activation via a phosphatidylinositol-anchored cell adhesion/signalling mechanism. Br. J. Haematol. 96: 647-653.

Hao, Q.-L., Shah, A.J., Thiemann, F.T., Smogorzewska, E.M. and Crooks, G.M. (1995). A functional comparison of CD34+CD38-cells in cord blood and bone marrow. Blood 86: 3745-3753.

Harris, D.T., Schumacher, M.J., Rychlik, S., Booth, A., Acevedo, A., Rubinstein, P., Bard, J. and Boyse, E.A. (1994). Collection, separation and cryopreservation of umbilical cord blood for use in transplantation. Bone Marrow Transplant. 13: 135-143.

Hows, J.M., Bradley, B.A., Marsh, J.C.W., Luft, T., Coutinho, L., Testa, N.G. and Dexter, T.M. (1992). Growth of human umbilical-cord blood in longterm haemopoietic cultures. Lancet 340: 73-76.

Mayani, H. (1996). Composition and function of the hemopoietic microenvironment in human myeloid leukemia. Leukemia 10: 1041-1047.

Mayani, H. and Lansdorp, P.M. (1995). Proliferation of individual hematopoietic progenitors purified from umbilical cord blood. Exp. Hematol. 23: 1453-1462.

Milosevits, J., Pocsik, E., Schmidt, B., Remenyi, P., Intodi, Z.S., Reti, M., Batai, A., Illes, P., Mihalik, R., Petranyi, G.G. and Paloczi, K. (1995). Immunophenotypic and functional characteristics of haemopoietic cells from human cord blood. Scand. J. Immunol. 42: 493-500.

Morrison, S.J., Uchida, N. and Weissman, I.L. (1995). The biology of hematopoietic stem cells. Annu. Rev. Cell Dev. Biol. 11:35-71.

Sternberg, D., Peled, A., Shezen, E., Abramsky, O., Jiang, W., Bertolero, F. and Zipori, D. (1996). Control of stroma-dependent hematopoiesis by basic fibroblast growth factor: stromal phenotypic plasticity and modified myelopoietic functions. Cytokines Cell Mol. Ther. 2: 29-38.

Tang, J., Nuccie, B.L., Ritterman, I., Liesveld, J.L., Abboud, C.N. and Ryan D.H. (1997). TGF-beta down-regulates stromal IL-7 secretion and inhibits proliferation of human B cell precursors. J. Immunol. 159: $117-125$.

Thierry, D., Hervatin, F., Traineau, R., Brossard, Y., Stark, R., Benbunan, M. and Gluckman, E. (1992). Hematopoietic progenitor cells in cord blood. Bone Marrow Transplant. 9 (Suppl 1): 101-104.

Waller, E.K., Olweus, J., Lund-Johansen, F., Huang, S., Nguyen, M., Guo, G.-R. and Terstappen, L. (1995). The "common stem cell" hypothesis reevaluated: human fetal bone marrow contains separate populations of hematopoietic and stromal progenitors. Blood 85: 2422-2435.

Wilkins, B.S. and Jones, D.B. (1995). Immunohistochemical characterization of intact stromal layers in long-term cultures of human bone marrow. Br. J. Haematol. 90: 757-766.

Ye, Z.-Q., Burkholder, J.K., Qiu, P., Schultz, J.C., Shahidi, N.T. and Yang, N.S. (1994). Establishment of an adherent layer from human umbilical cord blood for support of long-term hematopoietic progenitor cell growth. Proc. Natl. Acad. Sci. USA 91: 12140-12144.

(Received July 7, 1999) 